УДК 336.77.067:631

(C) 2012

\author{
Дадашев Б. А., доктор економічних наук, \\ Черемісіна С. Г., доктор економічних наук \\ Севастопольський інститут банківської справи \\ Української академії банківської справи Національного банку України
}

\title{
КРЕДИТУВАННЯ АГРОФОРМУВАНЬ: ПРОБЛЕМИ ТА НАПРЯМИ СТАБІЛІЗАЦІЇ
}

\section{Рецензент - доктор економічних наук В. В. Россоха}

Проаналізовано стан та основні проблеми розвитку кредитування в аграрній сфері Украӥни. Узагальнено характерні ознаки й обтрунтовано необхідність кредитного забезпечення діяльності сільськогосподарських товаровиробників у сучасних умовах господарювання. Розглянуто особливості діяльності аграрних підприсмств, що впливають на їх відносини з комериійними банками. Встановлено головні причини, щчо стримують активізацію кредитних механізмів у агропромисловому комплексі. Визначено найважливіші напрями кредитування аграрних формувань.

Ключові слова: кредит, кредитний механізм, пільтове кредитування, фінансові ресурси, інвестииіі, залучені кошти, фінансове забезпечення, державна підтримка.

Постановка проблеми. Завершення перебудови аграрного сектора економіки України на ринкових засадах, на жаль, не сприяло стабілізації й підвищенню ефективності аграрних формувань. Загострюється проблема зниження ефективності сільськогосподарського виробництва галузі, продовольчої безпеки та зростання імпортної залежності агропродовольчого ринку країни. Хронічний брак фінансових ресурсів у суб'єктів господарювання, передусім обігових коштів у період проведення сільськогосподарських робіт у землеробстві, зумовлює суттєве зниження оптових цін на продукцію галузі за одночасного зростання роздрібних цін на продовольство.

Однією 3 актуальних проблем аграрного сектора вітчизняної економіки $\epsilon$ подолання існуючих перешкод щодо поліпшення та розширення кредитного забезпечення сільськогосподарських товаровиробників. Із часу здобуття Україною незалежності проблеми, пов'язані з кредитуванням сільськогосподарських підприємств, набули значного загострення, внаслідок чого фінансовий стан агроформувань із року в рік погіршувався. Таким чином, складність проблем кредитного забезпечення сільськогосподарських товаро- виробників зумовлює необхідність глибшого дослідження теоретичних, методичних і практичних питань щодо розв'язання найболючіших проблем українського села.

Зазначимо, що потреба в банківському кредитуванні агроформувань постійно зростає й загострюється. Однак темпи його розширення в останні роки зменшуються. Це потребує виявлення причин, що стримують розвиток банківського обслуговування аграрного сектора України, та розробки пропозицій щодо поліпшення ситуації.

Аналіз основних досліджень i публікацій, у яких започатковано розв'язання проблеми. Проблеми кредитування досліджуються багатьма вченими-аграріями. Вагомий внесок у дослідження й розв'язання зазначених проблем зробили: П. Т. Саблук, М. Я. Дем'яненко [3], В. М. Алексійчук, С. А. Буковинський, О. Д. Василик, І. М. Брюховецький, А. І. Даниленко [6],

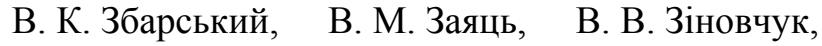
П. А. Лайко, І. О. Лютий, В. Я. Мессель-Веселяк, В. П. Рябоконь, С. С. Осадець, Г. М. Підлісецький, А. М. Поддєрьогін, Д. В. Полозенко, $\begin{array}{lll}\text { В. М. Федосов, С. І. Юрій, } & \text { В. Г. Андрійчук, }\end{array}$ І. Г. Кириленко [4] та ін.

Вченими-економістами досліджено основну частину теоретичних, методологічних та прикладних аспектів проблеми забезпечення сільськогосподарських товаровиробників банківськими фінансовими ресурсами. Однак проблема розвитку банківського кредитування агроформувань залишається невирішеною й продовжує загострюватися.

Залишаються недостатньо дослідженими аспекти системної взаємодії банківської системи і підприємств агропромислового виробництва на макро- і мікроекономічному рівнях.

Метою статті $\epsilon$ дослідження проблем розвитку кредитного механізму в аграрній сфері економіки України на макро- та мікроекономічному рівнях, а також розробка науково-практичних пропозицій щодо їх розв'язання. 
Результати дослідження. Дослідження фінансового забезпечення підприємств АПК, у тому числі сільськогосподарських товаровиробників, свідчить про те, що вони в основному працюють за рахунок власних ресурсів, частка яких у виробничій діяльності значна, проте недостатня для самофінансування. Обмеженість власних коштів змушує аграрні підприємства сподіватися на підтримку з боку держави й зумовлює необхідність розвивати як банківські, так і партнерські форми кредитування.

Необхідність та особлива роль кредиту, без якого сільськогосподарське підприємство як товаровиробник не може існувати, зумовлені специфікою його відтворювального процесу. Останнє, в свою чергу, вимагає врахування об’єктивних вимог галузі в процесі організації іiі кредитного обслуговування.

Терміни кредитування визначаються, виходячи 3 тривалості виробничого циклу позичальника на основі строків оборотності коштів, які зумовлені сезонністю. Остання спричиняе тимчасовий розрив між авансуванням грошових коштів та їх поверненням після реалізації продукції. Протягом цього періоду авансований капітал залишається у формі виробничих запасів і незавершеного виробництва, що збільшує період його обороту. Тривалий період виробництва в сільському господарстві й уповільнений оборот авансованого капіталу зумовлюють потребу в залученні короткострокових кредитних ресурсів на строк, довший, порівняно з іншими галузями національного господарства, що становить 6-9 місяців для покриття тимчасових потреб у рослинництві й майже півтора роки - у тваринництві.

Крім того, об'єктивною є вимога щодо своєчасного надходження кредитів у чітко визначені періоди року й у потрібному обсязі, поскільки більшість технологічних операцій повинні виконуватись у встановлені строки і мають незворотний характер. Затримка у здійсненні або невиконання окремих технологічних операцій може призвести до значних проблем виробничого процесу.

В аграрних підприємств виникає й тимчасовий розрив між потребою в оборотному капіталі та наявністю власних оборотних коштів, оскільки для забезпечення неперервності поточного циклу виробництва необхідно нагромаджувати значні запаси матеріальних ресурсів [2].

Окрім того, внаслідок макроекономічної дестабілізації (інфляція, диспаритет цін на сільськогосподарську продукцію і спожиті матеріально-технічні ресурси промислового виробництва, криза неплатежів) оборотні кошти сільськогосподарських підприємств були фактично втрачені, а відновити їх за рахунок власних джерел фінансування сільськогосподарські товаровиробники не в змозі.

Зазначимо, що протягом останніх десяти років кредити були й залишаються недоступними через низьку кредитоспроможність та відсутність необхідної для банку застави. Водночас для іноземних інвесторів низькоприбутковий і високоризиковий аграрний сектор України й досі залишається інвестиційно непривабливим. Частка кредитних ресурсів в обслуговуванні оборотних засобів у сільському господарстві досягла критичної межі, що зумовлює необхідність розробки і впровадження нової кредитної політики, спрямованої на створення економічних умов для ефективного використання кредитних ресурсів, прискорення структурної перебудови економіки та її соціальної орієнтації.

Зазначене свідчить, що вітчизняні товаровиробники галузі відчувають підвищену потребу в кредитних коштах, які нині $\epsilon$ важливим джерелом відновлення втраченого оборотного й основного капіталу.

Незалежно від чинників ціноутворення на кредитному ринку, сільськогосподарські підприємства потребують встановлення невисокого розміру плати за користування кредитними ресурсами. Така об'єктивна вимога спричинена низькою прибутковістю сільськогосподарського виробництва, порівняно 3 іншими галузями національного господарства, а, відповідно, й неспроможністю сплачувати кредитору ринковий відсоток за одержаний кредит [3].

Окрім усього, сільськогосподарське виробництво є низькотоварним, оскільки значна частка продукції (30-40 \%) не набуває товарної форми і використовується в натуральній формі в наступних циклах відтворення у вигляді насіння, кормів власного виробництва, молодняку тварин тощо. Нетоварна продукція не проходить стадії реалізації, тобто сільськогосподарське підприємство не одержує виручки та закладеного у ній прибутку.

Більшість видів сільськогосподарської продукції $€$ предметами першої необхідності й мають низьку еластичність попиту. Крім того, з метою соціальної стабільності ріст цін контролюється державою, що $є$ також причиною невисоких доходів сільськогосподарських підприємств. Поглиблює проблему низької дохідності вітчизняних товаровиробників сільськогосподарської продукції диктат і свавілля з боку посередників 
та перекупників, які знижують ціни на продукцію майже до рівня самоокупності.

Механізми державного регулювання і підтримки оптимального рівня доходів сільськогосподарських підприємств, дотримання еквівалентності обміну між товаровиробниками різних галузей практично не діє.

Отже, специфіка виробничого процесу в сільському господарстві зумовлює необхідність виконання в процесі організації кредитного обслуговування сільськогосподарських товаровиробників певних вимог стосовно порядку погашення кредиту та сплати відсотків за користування ним. Банки повинні враховувати, що всі платежі за кредитними зобов'язаннями сільськогосподарські товаровиробники мають здійснювати по мірі одержання виручки від реалізації сільськогосподарської продукції, строки надходження якої різняться залежно від спеціалізації господарств.

За даними департаменту фінансів Міністерства аграрної політики і продовольства України, у 2010 р. підприємства агропромислового комплексу отримали кредитів на суму 10,1 млрд грн, що на $74 \%$ більше порівняно 3 відповідним періодом 2009 року. Протягом 2010 р. 2238 підприємств галузі отримали кредити. Водночас спостерігалися помітні позитивні зрушення в обсягах кредитування суб'єктів господарювання аграрного сектора.

У структурі залучених коштів найбільша частка (70\%, або 7 млрд грн) припадала на короткострокові (до 12 місяців) кредити, а $30 \%$ становили середньострокові (до 36 місяців) - 1,4 та довгострокові (до 60 місяців) - 1,7 млрд грн.

Найактивніше кредитування агропідприємств проводилося у Черкаській, Полтавській та Харківській областях. Кредитування агропідприємств у 2006-2010 рр. здійснювали понад 110 комерційних банків і кредитних спілок, серед яких лідерами за обсягами були ТОВ КБ «Фі- нансова ініціатива», ВАТ «Райффайзен Банк Аваль», ВАТ «Державний експортно-імпортний банк» (Укрексімбанк); за кількістю позичальників - ВАТ «Райффайзен Банк Аваль», ЗАТ АКБ «Промислово-інвестиційний банк» (Промінвестбанк), ВАТ «Державний ощадний банк України» (Ощадбанк), які входять до переліку найбільших банків України.

Незважаючи на обсяги банківських кредитів, ставки користування аграрних підприємств залученими коштами зберігалися на високому рівні: так, у 2009-2010 рр. вони коливалися в межах 16-36 \%. За даними НБУ, у грудні 2010 р. середньозважена ставка за кредитами, наданими у сільське господарство, мисливство та лісове господарство, становила 14,9 \% за середньої ставки $14 \%$ річних [1, с. 122].

Аналіз загальнодержавних і галузевих макропоказників розвитку економіки України свідчить про чітку тенденцію докризового поступального зростання й відносної стабілізації рівнів валового внутрішнього продукту держави та аграрної сфери (табл. 1). Протилежна тенденція простежується 3 динамікою кредитування економіки в цілому та агропромислового виробництва. Загальні обсяги наданих кредитів у масштабах економіки України за період із 2000 по 2008 рр. збільшилися у 36 разів, а в аграрну сферу лише у 10 (iз 2,1 до 20,1 млрд грн). Обсяги кредитування економіки збільшувалися щорічно на 57 \%, а в аграрному секторі - лише на 32,8 \%.

У післякризовий період відбулося суттєве зменшення обсягів кредитування - від 724,2 до 501,0 млрд грн, а в аграрному секторі - від 20,1 до 9,7 млрд грн. Зазначимо, що частка кредитів в АПК у загальному обсязі кредитування мала сталу тенденцію до зменшення (перевищення показника посткризового 2010 р. над попереднім пояснюється фактично повним припиненням кредитування АПК у кризовому 2009 р.).

\section{1. Обсяги кредитування аграрної сфери економіки в динаміці, млрд грн}

\begin{tabular}{|c|c|c|c|c|c|c|c|}
\hline Показник & 2000 p. & 2005 p. & 2006 p. & 2007 p. & 2008 p. & 2009 p. & 2010 p. \\
\hline $\begin{array}{c}\text { Валовий внутрішній продукт } \\
\text { України }\end{array}$ & 170,1 & 441,5 & 544,2 & 720,7 & 948,1 & 914,7 & 1085,9 \\
\hline Валовий продукт АПК & 77,9 & 92,6 & 94,9 & 88,8 & 104 & 104,1 & 101,1 \\
\hline $\begin{array}{c}\text { Всього обсяги наданих кредитів } \\
\text { у економіку країни }\end{array}$ & 19,6 & 143,4 & 245,2 & 426,9 & 724,2 & 703,5 & 501,0 \\
\hline Обсяги кредитування АПК & 2,1 & 10,4 & 12,8 & 14,6 & 20,1 & 5,8 & 9,7 \\
\hline Питома вага кредитів АПК, \% & 10,7 & 7,3 & 5,2 & 3,4 & 2,8 & 0,8 & 1,9 \\
\hline
\end{tabular}

Джерело: [7] 
Якщо загальний обсяг кредитів у 2009 р. зменшився від 724,2 млрд грн до 703,5 млрд грн (тобто на 2,9\%), то обсяг кредитування аграрного сектора зменшився від 20,1 до 5,8 млрд грн, або на $71,1 \%$. С підстави вважати, що скорочення обсягів кредитування економіки приблизно на 70 \% відбулося, здебільшого, за рахунок зменшення кредитування аграрного сектора. Практично аналогічна ситуація спостерігалася під час фінансування української економіки в цілому, після того як вона була визнана надзвичайно ризиковою для інвесторів [5].

Навіть під час економічного зростання банківська система надавала перевагу кредитуванню не аграрної сфери, а інших галузей економіки. За умов економічної кризи загальне скорочення обсягів кредитування відбувається переважно за рахунок обмеження кредитування АПК. Банки починають застосовувати дискримінаційний механізм по відношенню до сільськогосподарських підприємств, тобто підвищують ставки кредитування, порівняно із суб'єктами господарювання інших галузей економіки.

Державна підтримка сільськогосподарських підприємств через механізм здешевлення позик сприяє підвищенню рівня їх забезпечення кредитними ресурсами. Кредитне забезпечення АПК, окрім інших факторів, суттєво залежить від суми коштів Державного бюджету, спрямованих на програму здешевлення позик АПК [6, с. 33].

Iз 2000 р. запроваджено механізми пільгового кредитування, відповідно до яких компенсація частини кредитної ставки комерційних банків із Державного бюджету здійснюється до 1 грудня поточного року. Впровадження з 2004 р. механізму здешевлення не лише короткострокових, а й довгострокових кредитів (понад 1 рік), а також зростання довіри кредиторів до сільськогосподарських позичальників сприяло збільшенню термінів кредитування підприємств галузі як на ринкових, так і на пільгових умовах. Зокрема, у 2005 році $52,0 \%$, а у 2006 р. - 58,0 \% кредитів, наданих банками сільськогосподарським товаровиробникам, були довгостроковими. Проте у кризовому 2009 р. ситуація вкрай погіршилась - обсяги наданих агроформуванням кредитів зменшились, а процентні ставки зросли до 20-25\% [4].

Цілком зрозуміло: розвитку банківського кредитування аграрної сфери сприятиме зростання мотивації комерційних банків, що формується під впливом допустимого рівня кредитного ризику, реального (кредитоспроможного) попиту позичальників на банківський кредит, наявної ресурсної бази кредиторів.
Кредитні відносини з підприємствами аграрного сектора для банків були й залишаються ризикованими. 3-поміж основних видів ризиків можна виділити сезонність виробництва і попиту на продукцію (3 цим пов'язані коливання обсягів грошових надходжень і платоспроможність позичальника), високу залежність результатів господарювання від погодних умов, недостатню ліквідність застави, що пропонується в забезпечення кредиту; необхідність формування кредитором значних страхових резервів на покриття можливих втрат від проведення кредитних операцій, що знижує рентабельність цих операцій, нерозвиненість страхового ринку в країні, який нині забезпечує сільськогосподарським товаровиробникам формальний страховий захист; операційні ризики, пов'язані $з$ недосконалістю банківських технологій і відсутністю у банків досвіду роботи із сільськогосподарськими позичальниками.

Визначальним у кредитуванні АПК $\epsilon$ процес здешевлення кредитів, адже пільгові кредити в середньому становлять $60 \%$ загального обсягу. Середня відсоткова ставка, що компенсується за рахунок бюджетних коштів, становить приблизно 10,9\%. Обсяг пільгового кредитування істотно залежить від обсягу коштів, передбачених державним бюджетом на пільгове кредитування, а цей показник має тенденцію непостійності й зменшення. Так, частка бюджету, що виділяється на здешевлення кредитів, знаходиться в межах від 0,1 до $0,5 \%$.

Рівень кредитоспроможності агроформувань знаходиться на низькому рівні: майже 40 \% підприємств аграрного сектора в 2011 р. залишаються збитковими, темпи розвитку низькі й нестабільні (табл. 2).

Сільськогосподарські підприємства мають вкрай незадовільну структуру активів. У загальній вартості майна понад $76 \%$ припадає на необоротні активи, переважну частку яких становлять основні засоби, що є неліквідними через високий рівень (70-80 \%) зносу й моральну застарілість.

Слід вказати на обмежені можливості банків щодо стягнення проблемних та безнадійних боргів внаслідок недосконалості законодавчої бази. Тому високі ризики кредитування підприємств аграрної сфери вони компенсують високими відсотковими ставками й жорсткими вимогами до позичальників. Недосконала структура банківської системи також гальмує розвиток кредитних відносин 3 аграрним сектором економіки. Відсутність таких необхідних елементів як кооперативний банківський сектор, спеціалізованих банків (іпотечного, аграрного) створює галузеві диспропорції у кредитуванні. 


\section{2. Динаміка показників, що характеризують кредитоспроможність} сільськогосподарських підприємств

\begin{tabular}{|c|c|c|c|c|c|c|c|c|c|c|c|}
\hline Показник & 2000 p. & 2001 p. & 2002 p. & 2003 p. & 2004 p. & 2005 p. & 2006 p. & 2007 p. & 2008 p. & 2009 p. & 2010 p. \\
\hline $\begin{array}{c}\text { Продукція } \\
\text { с.-г. в порів- } \\
\text { няльних } \\
\text { цінах, \% до } \\
\text { попередньо- } \\
\text { го року }\end{array}$ & 109,8 & 110,2 & 101,2 & 89,0 & 119,7 & 100,1 & 102,5 & 93,5 & 117,1 & 98,2 & 98,5 \\
\hline $\begin{array}{c}\text { Збиткові } \\
\text { підприємст- } \\
\text { ва, \% до } \\
\text { загальної } \\
\text { кількості }\end{array}$ & 34,5 & 43,9 & 53,8 & 50,5 & 33,8 & 36,2 & 4,7 & 32,2 & 35,7 & 37,5 & 38,4 \\
\hline $\begin{array}{c}\text { Рівень суку- } \\
\text { пної рента- } \\
\text { бельності } \\
\text { (збитковос- } \\
\text { ті) галузі, \% }\end{array}$ & $-1,0$ & 18,3 & 4,9 & 12,6 & 8,1 & 6,8 & 2,8 & 15,6 & 13,4 & 13,8 & 16,9 \\
\hline
\end{tabular}

Джерело: [8]

Активне монетарне стимулювання Національним банком України діяльності банків стимулює зростання обсягів кредитних операцій. Проте адекватного зниження кредитних ставок не відбувається. Зменшення облікової ставки є передумовою для здешевлення вартості кредитних ресурсів, оскільки для комерційних банків вона $\epsilon$ орієнтиром вартості грошей. Однак в Україні за останні роки, на відміну від економічно розвинених країн світу, вплив цього інструменту грошово-кредитної політики держави на рівень кредитної ставки за банківськими кредитами значно послабився, що підтверджує високий рівень відсоткового спреду між кредитною ставкою комерційних банків та обліковою ставкою НБУ.

Отже, на розвиток кредитних відносин банків і сільськогосподарських позичальників впливають різні фактори, головними з яких $\epsilon$ фінансовий стан позичальника, наявність ліквідної застави, реальність страхового захисту, рівень кредитоспроможного попиту сільськогосподарських підприємств на банківські кредити та ін.

Проведений аналіз зазначених факторів показує, що більшість із них на даному етапі (при загальній позитивній тенденції до змін) продовжують стримувати розвиток кредитних відносин аграрних підприємств із комерційними банками.

Аналіз існуючої практики кредитування банками підприємств агропромислового виробництва України дає змогу виділити такі їі особливості:

- банки видають кредити переважно на строк від шести до дванадцяти місяців, хоча останнім часом набуває розвитку середньострокове кредитування терміном до 2-3 років;

- процедура отримання банківського кредиту для підприємств аграрного сектора залишається ускладнено-бюрократизованою, потребує надання значної кількості необхідних документів i тривалого періоду їхнього розгляду;

- наявність досить широкої диференціації умов кредитування клієнтів залежно від виду забезпечення, строку кредитування, надійності клієнта, мети кредитування, обсягу кредиту тощо;

- складність визначення обсягу та компонент забезпечення кредитів (для забезпечення використовуються ліквідні товарно-матеріальні цінності, зібраний або майбутній врожай, сільськогосподарська техніка, основне стадо тощо);

- наявність із боку банків контролю фінансово-господарського стану позичальника протягом усього строку кредитування. Крім фінансових показників діяльності контролюється стан посівів, своєчасність проведення необхідних агротехнічних заходів і хід збирання врожаю;

- використання майже всіх юридичних можливостей для повернення кредитів позичальниками (залучення до цієї роботи фахівців служби економічної безпеки банку та спеціалістів сільського господарства).

Відсутність дієвого механізму застави майна стримує розвиток банківського кредитування сільськогосподарських підприємств. Об'єктом застави може бути земля, проте, враховуючи високий ступінь ризику неповернення кредитів, 
існує ризик часткової втрати земель сільськогосподарського призначення товаровиробниками i переходу їх у власність банків. Ступінь захищеності прав кредиторів і можливість проведення різноманітних комерційних операцій передбачені чинним законодавством, але недосконала нормативно-правова база захисту сільськогосподарських товаровиробників із боку держави в процесі фінансово-кредитних відносин.

Оцінка заставного майна проводиться оцінювачами банку, виходячи 3 існуючої ринкової (а не балансової) вартості на конкретний вид застави за винятком дисконту банку. Оціночна вартість застави перевищує обсяг кредиту в 1,5-3 рази.

Значна кількість підприємств не має кредитної історії; в багатьох банках відсутній кваліфікований персонал для оцінки стану та перспектив розвитку бізнесу саме в аграрного позичальника; не налагоджений облік господарської та фінансової діяльності аграрних підприємств. Усе це обмежує обсяги кредитування банками аграрного бізнесу, призводячи до підвищення вартості кредитних ресурсів.

Практика кредитування підприємств аграрної сфери свідчить, що банки досить часто стикаються 3 проблемою правильного визначення розміру кредиту для позичальника. Недостатня сума кредиту підвищує кредитний ризик, оскільки у позичальника може виникнути дефіцит обігового капіталу для повного здійснення виробничого процесу, що поставить банк перед вибором: дати додатковий кредит або втратити раніше наданий. Надання занадто великої суми кредиту підвищує витрати позичальника на сплату процентів, що теж може погіршити його фінансовий стан.

Розмір відсоткових ставок для підприємств АПК і порядок їх сплати встановлюються банком і визначаються в кредитному договорі. Вартість кредиту для аграрного підприємства залежить від таких основних чинників:

- облікова ставка НБУ;

- середня відсоткова ставка за міжбанківськими кредитами;

- стан кредитного ринку та ступінь ризику кредитування;

- вид, величина та термін користування кредитом;

- попит на кредит, стабільність грошового обігу в країні;

- вартість кредитних ресурсів, які банк залучає на ринку;

- відсоткові ставки банків-конкурентів;
- рівень кредитних ризиків, притаманних певному кредитному проекту. Зокрема, чим більший термін кредитування, тим вища сплата відсоткової ставки.

На відсоткову ставку впливає також періодичність сплати відсотків та погашення кредиту, фінансовий стан підприємства, забезпечення повернення кредиту.

Джерелами погашення кредиту є доходи позичальника, а у разі його фінансової неспроможності - виручка від реалізації заставленого майна, кошти гаранта або страхової компанії.

Необхідно констатувати, що вітчизняна практика розробки внутрішніх нормативних документів, які мають регламентувати кредитну політику банку, зазвичай, не передбачає чіткого визначення всього комплексу питань кредитного процесу, що, з нашого погляду, безумовно, підвищує кредитні ризики в умовах постійних економічних змін.

Кредитна політика комерційного банку повинна передбачати процедури і механізми прийняття рішень стосовно надання й моніторингу стандартних кредитів, визначати перелік процедур погашення сумнівних і безнадійних до повернення кредитів та регламентувати питання управління кредитними ризиками і формування страхових резервів на покриття можливих збитків від проведення активних операцій.

Ключовим етапом у підготовчій роботі 3 клієнтом $є$ аналіз кредитоспроможності клієнта. Вивчення плато- та кредитоспроможності позичальника дає змогу визначити ступінь ризикованості кредитної операції для банку. Показники кредитоспроможності, що розраховуються банками, мають свою обмеженість, оскільки вони розраховуються на основі історичних даних балансу, а кредитоспроможність слід розраховувати на перспективу. Крім того, показники розраховуються на основі статичних, а не динамічних даних, що може впливати на їх необ' єктивність.

Проблемою для банків стає перевірка достовірності даних. Отримати інформацію про кредитну історію у нас в країні можна лише 3 даних, наданих клієнтом або накопичених самим банком. Створений Національним банком України реєстр недобросовісних позичальників може суттєво знизити кредитні ризики комерційних банків, однак немає ніяких гарантій того, що всі банки надають інформацію про проблемні кредити власних позичальників.

Зазначені фактори, безперечно, ускладнюють аналіз кредитної заявки й збільшують потенційні кредитні ризики. 
Кредитний моніторинг передбачає постійний контроль за діяльністю позичальника. Своєчасне виявлення погіршення основних фінансововиробничих індикаторів та показників діяльності агроформування-позичальника сприятиме зниженню вірогідності ризикових ситуацій і втрат кредитних ресурсів. Серед таких факторів можна виділити:

- несвоєчасність погашення кредиту та нарахованих відсотків, постійна зміна графіків погашення кредитів;

- зменшення обсягів реалізації продукції в порівнянні з відповідним періодом минулого року;

- зменшення частки грошових розрахунків (використання бартерних операцій);

- перевищення позичальником середньогалузевих норм заборгованості по відношенню до його капіталу;

- несприятливі погодні умови;

- зміни в галузі, на ринку або продуктах клієнта;

- наявність постійних збитків або їх різке зростання;

- зростання обсягів товарно-матеріальних запасів і дебіторської заборгованості, в тому числі простроченої;

- зростання обсягів кредиторської заборгованості, в тому числі простроченої;

- зменшення виплат або невиплата дивідендів, паїв та інших платежів власникам підприємства або по земельних паях, що використовуються позичальником;

- відсутність або ненадання банку фінансовогосподарської документації;

- погіршення коефіцієнтів ліквідності; небажання співробітничати з банком, відмова банку у проведенні перевірок діяльності позичальника, наявності та стану зберігання заставного майна;

- невикористання основних фондів (для сільськогосподарських підприємств - наявність необроблюваних земель, окрім пару);

- реалізація активів позичальника (транспорту, обладнання, будівель, основного стада);

- введення державою особливих режимів функціонування у сферах, де здійснює свою діяльність позичальник (квотування виробництва та реалізації продукції, запровадження нових стандартів до готової продукції, що виробляється позичальником тощо);

- зміна керівництва та ключових працівників підприємства, зміни в стилі управління.

Зауважимо, що зниження мотивації банків кредитування агроформувань може виникнути у зв'язку з дією факторів, що не знаходяться під контролем банку і позичальника.
Це можуть бути зміни законодавства, погіршення економічної ситуації, несприятливі погодні умови, запровадження нових технологій виробництва.

Аналіз та узагальнення практики банківського кредитування сільськогосподарських товаровиробників дає можливість зробити наступні висновки.

Банківське кредитування все ще не відіграє належної ролі у фінансуванні аграрного виробництва, про що свідчать недостатні обсяги кредитних вкладень банків у сільське господарство (2,4 \% ВВП країни), які є неспівставними з тією роллю, яку відіграє галузь в економіці країни, створюючи близько 1/5 ВВП України.

Окремі умови кредитного забезпечення (якісні параметри функціонування кредитних відносин) не відповідають сучасним потребам аграрного сектора економіки України й не враховують сповна об'єктивних вимог галузі через короткостроковість та високу вартість кредитних коштів.

Специфічними відмінностями кредитування підприємств АПВ $є$ підвищена ризикованість кредитного портфелю, пов'язана 3 вразливістю сільськогосподарського виробництва і залежністю платоспроможності позичальників від погодних умов та державної політики регулювання аграрного ринку; циклічність надання і погашення кредитів, зумовлена сезонністю виробництва й реалізації продукції.

Кредитування аграрних підприємств має здійснюватись у чітко передбачені строки і з дотриманням принципу адекватності кредитування, поскільки несвоєчасність надання та неадекватність суми кредиту може призвести до порушення технології проведення сільськогосподарських робіт i, як наслідок, - до недоотримання врожаю.

Розвиток та удосконалення кредитних відносин сільськогосподарських підприємств із комерційними банками суттєво залежить від підвищення їх кредитоспроможності та ліквідності забезпечення кредитів. Зниження кредитних ризиків і підвищення ефективності кредитування аграрних підприємств можливе завдяки розробці та впровадженню в практичну діяльність банку методик аналізу кредитоспроможності з урахуванням галузевої особливості позичальників.

Підвищенню ефективності кредитування аграрного сектора економіки сприятимуть дієві заходи в плані роботи з проблемною і сумнівною заборгованістю позичальників, щодо використання усіх можливих шляхів реструктуризації та погашення таких кредитів у разі виявлення перших ознак проблемності. 
Висновки. Встановлено, що проблема кредитної підтримки сільського господарства полягає не лише у відсутності передумов для отримання ними фінансових ресурсів і повернення кредитних коштів, а й у відсутності дієвого механізму державної підтримки.

Основними напрямами щодо стабілізації механізму кредитування сільськогосподарських підприємств $є$ комплекс заходів із боку держави та банківської системи, спрямованих на розвиток дієвого інтеграційного механізму взаємодії з аг-

\section{БІБЛІОГРАФІЯ}

1. Аранчій В. I. Кредит у системі фінансового забезпечення інвестиційного розвитку аграрних підприємств / В. І. Аранчій, О. П. Зоря, І. І. Петренко // Вісник Полтавської державної аграрної академії. - 2011. - № 4. - С. 120-124.

2. Гудзь О. С. Фінансові ресурси сільськогосподарських підприємств / Гудзь О. Є. - К. : ННЦ IAE, 2007. $-578 \mathrm{c}$.

3. Дем'яненко М. Я. Кредитування сільськогосподарських підприємств: теорія і практика / М. Я. Дем'яненко // Облік і фінанси АПК. 2005. - № 7. - С. 9-19.

4. Кириленко I. Г. Деякі аспекти державної аграрної політики в Україні в умовах світової фінансової кризи / І. Г. Кириленко // Економіка АПК. - 2008. - № 11. - С. 4-9. рарним сектором економіки; розробка і застосування всіх можливих джерел для залучення капіталу при кредитуванні сільського господарства (раціональне використання бюджетних коштів, збільшення бюджетних асигнувань, залучення іноземних кредитів, створення за їх рахунок механізмів державного, банківського або змішаного кредитування); вирішення майнового і земельного питань, а також проблем існуючих заборгованостей сільськогосподарських підприємств.

5. Скрипник A. Основні аспекти і параметри оцінки ймовірності дефолту України в умовах фінансової кризи / А. Скрипник, С. Марченко // Вісник Національного банку України. - 2009. № 3. - C. 10-19.

6. Скрипник А., Ткаченко О. Інформаційна складова підвищення ефективності кредитування аграрного сектору / А. Скрипник, О. Ткаченко // Вісник Національного банку України. - 2011. № 11. - С. 32-35.

7. Матеріали офіційного сайту Національного банку України [Електронний ресурс]. - Режим доступу : http://www.bank.gov.ua.

8. Матеріали Державної служби статистики України [Електронний ресурс]. - Режим доступу : http://www.ukrstat.gov.ua 